\title{
607 表面改質を施した鉄鋼材料の高温度域エロージョン摩耗特性
}

High temperature erosion wear characteristic of surface modificated steel material

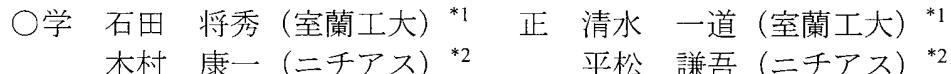

Masahide ISHIDA, Kazumichi SHIMIZU*1 Muroran Institute of Technology, Mizumoto-cho2 7-1, Muroran, Hokkaido Kohichi KINURA, Kengo HIRAMATU*22Nichias Corporation, 1-26,Shibadamon1-chome, Minato-ku, Tokyo

Key Words:Wear, Erosion, Erosion rate, High temperature, Surface modification, Overay welding

\section{1. 緒言}

エロージョン摩耗とは, 流体内の粉体が材料に衝突し, 被 衝突材料の表面から材料を損傷, 除去する現象である。種々 の粉体輸送プラント等で問題となる中, 特に溶融スラグを原 料として製繊を行うローターにおいて, 高温環境下でのエロ ージョン摩耗が生じ, 高温エロージョン摩耗メカニズムの解 明とその対応策が喫緊の課題である。これまでの研究におい て, 高温度域では常温よりも摩耗量が増加し, 延性材料特有 の角度依存性を示すことが明らかになっている。122

そこで本研究では, 耐高温エロージョン摩耗性向上を目的 として, 表面改質を施した材料の高温度域エロージョン摩耗 試験を行った結果を報告する。

2. 実験方法

表面改質として，肉盛溶接を施した材料を用意した。母材 はSUS410 とし，而摩耗性に優れる高クロム系(以下 6006), WC 系(以下 6088), 多量炭化物系(以下 6715)の 3 種類の硬質 層で肉盛を施した。一方, 比較材として母材である SUS410 を用意した. Table 1 にSUS410 および各種肉盛溶接材の主成 分と硬さを, Fig.1 に組織写真を示す. 実験には高温エロー ジョン摩耗試験機を用い, 試験片寸法は $50 \times 50 \times 10 \mathrm{~mm}$ とし, 各種肉盛溶接材については同様のサイズの母材に対し, 約 $3 \mathrm{~mm}$ の肉盛を施したのち, 平面研削を行った. 6006 の溶接 材料では厚みを出すために 1 層目に軟質層を， 2 層目に硬質 層を，各 $3 \mathrm{~mm}$ 施した後平面研削を行った。実験条件は，供 試材温度 $900^{\circ} \mathrm{C}$, 粉粒体温度 $800^{\circ} \mathrm{C}$, 熱風温度 $500^{\circ} \mathrm{C}$, 空気流 速 $100 \mathrm{~m} / \mathrm{s}$ とし, 粉粒体には硬さ $1140 \mathrm{HV}$ の球形アルミナグ リット(平均粒径 $1.16 \mathrm{~mm}$ )を用いた。粉粒体総重量を $8000 \mathrm{~g}$ とし, 衝突角度は 30,60 および $90 \mathrm{deg}$.とした. 摩耗量の評 価については, 密度の異なる材料の耐エロージョン摩耗特性 を比較するために, 損傷速度 $\left(\mathrm{cm}^{3} / \mathrm{kg}\right)$ を用いて摩耗量の評価 を行った。実験後には, 各供試材の摩耗表面観察を行い, 摩 耗メカニズムの考察を行った.

\section{3.実験結果及び考察}

Fig. 2 に各供試材の損傷速度と衝突角度の関係を示す. 6715 の肉盛溶接材については, 実験後すべての衝突角度で重量が 増加していた。実験後の供試材において酸化スケールが確認 できたことから酸化の影響が大きいと推察され，損傷速度が 正確に求めることができない為, 耐高温エロージョン摩耗性 には優れていないと考えられる。 そのほかの供試材 6088,

Tablel. Main chemical components and Vickers hardness

\begin{tabular}{|c|c|c|}
\hline & $\begin{array}{c}\text { Main chemical } \\
\text { components }\end{array}$ & Vickers hardness(HV) \\
\hline SUS410 & Fe, Cr, Ni, C & 273 \\
\hline 6006 & $\mathrm{Fe}, \mathrm{Cr}, \mathrm{C}, \mathrm{Si}$ & $\begin{array}{c}\text { Matrix:694 } \\
\text { Carbide: } 1288\end{array}$ \\
\hline 6088 & WC, NI, Cr, B, Si & $\begin{array}{c}\text { Matrix:546 } \\
\text { Carbide: } 1885\end{array}$ \\
\hline 6715 & $\mathrm{Fe}, \mathrm{Cr}, \mathrm{Nb}, \mathrm{W}$, & $\begin{array}{c}\text { Matrix: } 857 \\
\text { Carbide: } 1108\end{array}$ \\
\hline
\end{tabular}

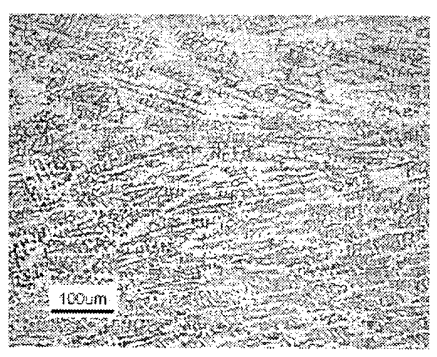

SUS410

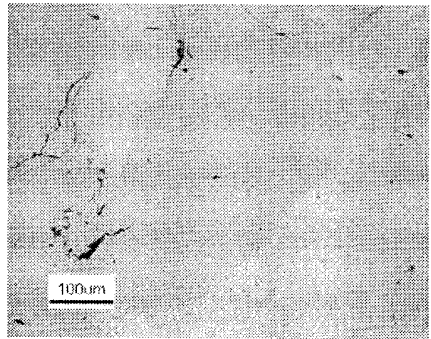

6088

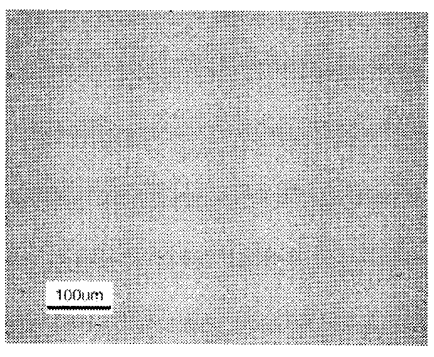

6006

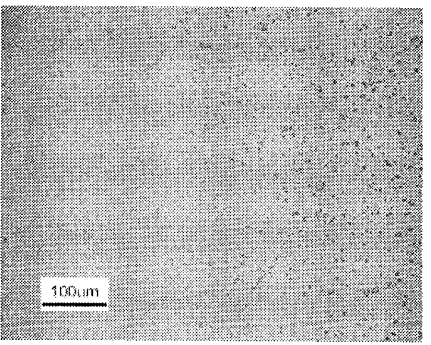

6715
Fig.1 Microstructure of specimens 
6006，SUS410 ともに低角度側において損傷速度が増加して いる傾向がある。これは延性材料特有の衝突角度依存性であ る. 特に 30deg. では顕著に損傷速度に差が表れており， SUS410 と比較し, 6088 では約 85\%損傷速度が増加しており， 6006 では約 50\%損傷速度が減少した結果となった。この理 由として, エロージョン摩耗の摩耗形態が衝突角度に依存す るという特徴に起因していると考えられる.エロージョン摩 耗は高角度側では変形摩耗,低角度側では切削摩耗となり， 60deg.では切削摩耗と変形摩耗が混合した摩耗形態であると 明らかになっている。このことから，高温度域において各供 試材は切削摩耗の影響が顕著に表れたと推察できる。

実験後の摩耗表面を Fig.3 に示す. SUS410 では低角度側に なるに従って凹凸が増えていた。 この凹凸は粉粒体と供試材 の衝突により塑性変形した際にできたものである．SUS410 では高温度域で軟化したためこの凹凸がはっきり表れたと 推察できる. 6088 では 30,60deg.の角度において凹凸確認は 見られなかったが，摩耗表面が抉り取られた形となっていた。 Fig.4に 6088 の摩耗表面の拡大写真を示寸.この写真の穴は 6088 に含まれているタングステンカーバイドの大きさとほ ぼ同等である. 今回見られた穴は高温により基地組織が軟化 したため, 粉粒体の衝突によってタングステンカーバイドが 剥がれ落ちた跡であると推察した. そのため損傷量が多くな り，6088の損傷速度が增加したと考えられる.6006では凹 凸がはっきりと確認できなかった。このことから，6006では 高温度域でもある程度硬さを保つことができたため，母材で あるSUS410 よりも表面の塑性変形が抑えられ，損傷速度が 低下したと考えられる.このことから，6006 肉盛溶接材は， 耐高温エロージョン摩耗性に優れると推察できる.

4.結言

高温度域エロージョン摩耗において, 表面改質を施すこと により, 表面近傍の塑性変形を抑えることが損傷速度の低下 につながる. よって表面改質は耐高温エロージョン摩耗性に とって有効な手段であるといえる.しかしながら, 高温度域で 酸化の影響が強い材料,炭化物とマトリックスの結合が弱い 材料などは損傷速度が大きくなり, 耐高温エロージョン摩耗 性に有効ではない場合もある。

\section{参考文献}

1)清水一道・ほか 4 名, 鉄鋼材料の耐エロージョン摩耗特性 評価, 日本機械学会第 9 回機械材料・材料加工技術講演会講 演論文集, 2001. 11

2)清水一道, 野口徹, 高崎秀人, 溶射を用いた表面改質材の エロージョン摩耗特性, 日本鋳造工学会第 127 回全国大会講 演概要集, 1995. 10

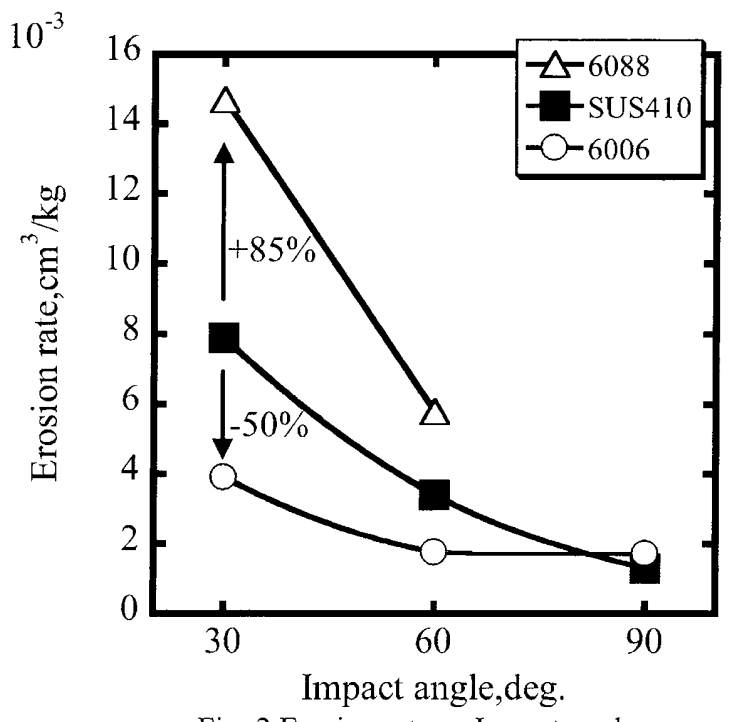

Fig. 2 Erosion rate vs Impact angle

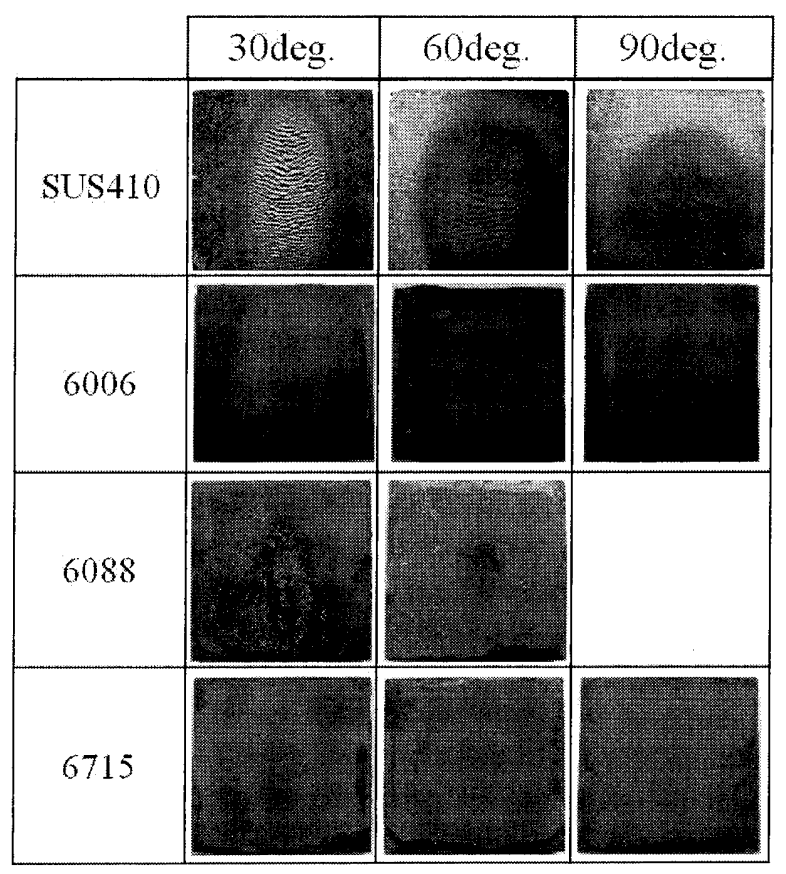

Fig. 3 Macroscopic observation of eroded surface at Impact angle of 30,60, and $90 \mathrm{deg}$.

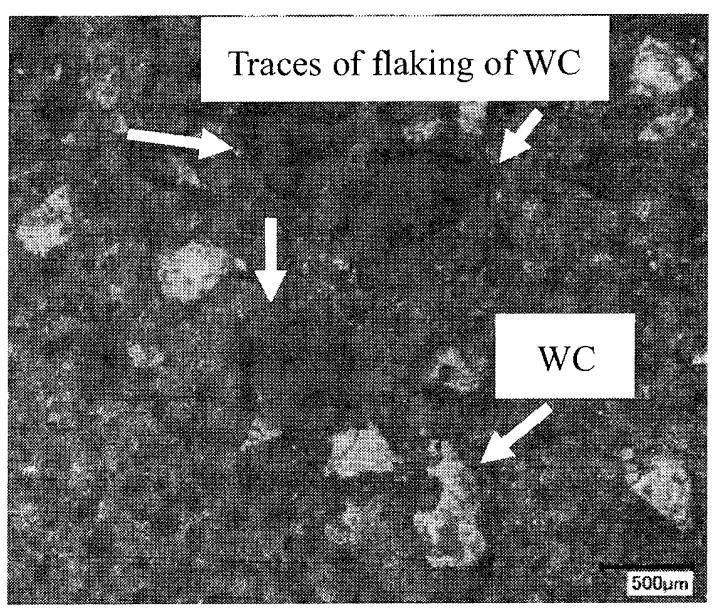

Fig. 4 Traces of flaking of WC on the eroded surface of 6088 at $30 \mathrm{deg}$. 